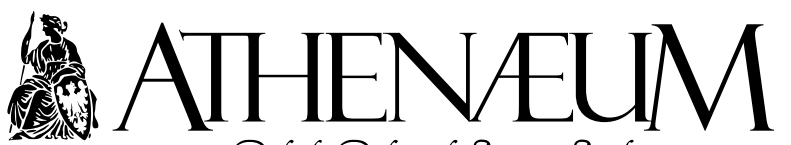

Polish Political Science Studies

Polskie Studia Politologiczne

vol. 68(4)/2020, pp. $160-176$

DOI:10.15804/athena.2020.68.11

www.athenaeum.umk.pl

ISSN 1505-2192

\title{
ESTONIAN WAY TO THE DIGITAL STATE: DETERMINANTS OF THE DEVELOPMENT OF THE REPUBLIC OF ESTONIA
}

\author{
ESTOŃSKA DROGA DO PAŃSTWA CYFROWEGO. \\ UWARUNKOWANIA ROZWOJU REPUBLIKI ESTONII
}

Kamila Sierzputowska*

\begin{abstract}
The text below is an attempt to describe circumstances of emerging and further phases of development of the Republic of Estonia with particular attention focused on geopolitical conditions of political, economic and social processes shaping the country and having impact on its international image. Depicting respective periods in the history of Estonia and conducting an analysis of the contemporary Republic of Estonia, the author of the article describes the way that this small Baltic state successfully made to become a modern digital state.
\end{abstract}

Keywords: independence; Estonia; ESSR; digital revolution; e-state; smart power
Tekst stanowi próbę zwrócenia uwagi na okoliczności powstania oraz kolejne etapy rozwoju Republiki Estonii, ze szczególnym uwzględnieniem geopolitycznych uwarunkowań procesów: politycznych, gospodarczych i społecznych, kształtujących kondycję tego kraju oraz wpływających na jego międzynarodowy wizerunek. Opisując poszczególne okresy w dziejach państwa estońskiego oraz dokonując analizy współczesnej Republiki Estonii, autorka artykułu stara się zobrazować drogę, jaką pokonał ten niewielki kraj bałtycki, by z sukcesem realizować formułę nowoczesnego państwa cyfrowego.

Słowa kluczowe: niepodległość; Estonia; ESRR; rewolucja cyfrowa; e-państwo; smart power

* Kazimierz Wielki University in Bydgoszcz, Faculty of Political Science and Administration. 


\section{INTRODUCTION}

Estonia, located in the north-eastern Europe, is the smallest of the Baltic states. Its rather low demographic potential (around 1.3 million) and the area $(45,227$ $\mathrm{km}^{2}$ ) make it one of Europe's smallest countries. During over 1,000-year history, Estonian lands were ruled by different powers - Sweden, Denmark, Germany, Poland, Rus, and in the $18^{\text {th }}$ century, they became a part of the Russian Empire for the two following centuries. For the first time Estonia became independent and an independent Estonian Republic was declared only in 1918, but it lasted merely two decades, as in 1940 it was incorporated into the Union of Soviet Socialist Republics. As the communist system collapsed in central and eastern Europe and the Cold War ended, on August 20, 1991, an independent Estonian state was restored. In less than three decades, after the Republic of Estonia declared independence, the country has gone through radical restructuring. The deliberate geopolitical shift successfully moved this little country towards a modern Nordic state (Piirimäe, 2011).

The author's goal is to present conditions for the development of the Estonian state in the $20^{\text {th }}$ and $21^{\text {st }}$ centuries, taking into account respective areas of its operation, and the results of political actions undertaken in the respective periods of the existence of Estonia and their impact on processes of shaping the nation's identity and on the capacity of the state development. Thus, the main goal is to present a synthetic picture of the fate of the Estonian nation with reference to consecutive phases of shaping its political organization (the statehood). It is significant here to provide answers to the following research questions: Which factors affected the process of shaping national identity of the Estonian people? What were the main challenges that the young Estonian state had to face? What were the main effects of the thorough transformation of the country? Why was it successful?

A starting point for reflections on the above issues is to present a wider context and a historic background of the turbulent period in the Estonian history before 1918, which played a fundamental role in shaping of the Estonian nation. The year 1918 (the final phase of WW1 and the still ongoing Russian revolution) and specifically the date of February 24, 1918, when the Provisional Government of the Republic of Estonia ${ }^{1}$ was formed by Konstantin Päts, have been adopted as the turning point when Estonian independence was declared for the first time, in order to present the process of the state reorientation and all the related consequences that occurred in the respective areas of its 100-year history. In 
order to systemize the complex history of the Estonian state it is necessary to periodize it, taking into account respective stages of the state's operation (political, administrative, legal systems, etc.):

I. The time before the independent Republic of Estonia was created on February 24, 1918.

II. 1918-1940: from gaining independence to incorporation into the Soviet Union as the Estonian Socialist Soviet Republic (ESSR) on August 6, 1940. III.1940-1991: from incorporation into the USSR to August 20,1991, when Estonia declared independence.

IV. 1992-2020: from formation of Mart Laar's centre-right government after 1992 elections to creation of a modern digital society.

The success of the conscious restructuring and a rapid acceleration that was the result of implementing modern IT solutions became the main indicators of the new image of the country. The contemporary reliability of Estonia as an e-state is mainly the effect of specific measures taken by the government. That conditioned reorientation and effective shaping of the state's international reputation of a modern republic, a pioneer in the field of digital transformation of the public sector. Today Estonia is the leader of both Baltic and Soviet transformation. The Estonian projection of the soft power based on a digital agenda is the final point that summarizes considerations over the evolution of this small Baltic republic.

A systems analysis method of was used in the article, presenting conditions of the development of the Estonian land, especially from gaining independence, taking into account respective areas of its functioning and effects of political processes occurring during respective periods of existence of the Estonian state and especially their impact on possibilities and directions of its development. The author used the historical analysis method to show the origin, course and significance of historical and political processes, to indicate a cause and effect relationship, to analyze and draw conclusions. The qualitative method was used to evaluate and explain the described events, showing a multi-basis process of transformation of the contemporary Republic of Estonia and its consequence for the current condition of the state. 


\section{HE FIRST INDEPENDENT ESTONIAN STATE}

Aesti tribes were of Finno-Ugric origin and inhabited the Baltic coast, the lands of today's Estonia (Raun, 2001). Tacitus, Roman historian, mentioned them for the first time in his work Germania, written around the year 98 (Tacyt, 1804). They had a patriarchal system based on clans ruled by elders. They lived in communities (maakonnad ${ }^{2}$ ), but did not create a state. For centuries the lands of today's Estonia were areas of constant conquests and conflicts. The Vikings, who traversed Estonia and Latvia to reach Slavic lands, were the first invaders. The $11^{\text {th }}$ and $12^{\text {th }}$ centuries were marked by expansion of princes of Rus, who did not manage to gain control over the land. In $12^{\text {th }}$ and $13^{\text {th }}$ centuries, Germans attempted to Christianize Estonians, but they failed (Bazylow, 1985). Later, the area was conquered by the Kingdom of Denmark. From the $16^{\text {th }}$ century the north of Estonia was under Swedish rule and the south was occupied by the Polish-Lithuanian Commonwealth as a part of Livonia. In the first half of the $17^{\text {th }}$ century the whole territory was dominated by Sweden. Finally, after Swedish forces had been defeated in the Great Northern War, Estonia, through decisions of the Treaty of Nystad (1721), was subordinated to the Tsardom of Russia and remained its part till WW1 (Forycki, 2007). After a very turbulent period of the Great Northern War, the following two centuries of Russian rule brought relative stabilization. Even though these were times of oppression of the aboriginal Estonian population within extensive Russification or spreading Orthodox Christianity, serfdom of peasants was abolished at the end of the first quarter of the $19^{\text {th }}$ century (Lewandowski, 2001).

Abolition of serfdom of peasants sped up the development of the Estonian territory and created material basis for the development of national culture as well as for the political national movement. Undoubtedly quick economic growth determined changes to the Estonian political and cultural life. Despite the ban on activity of political parties and despite the censorship, Estonians were active in the fields of culture and national identity through institutions of culture, education and the press. The beginnings of Estonian national movement are closely

\footnotetext{
${ }^{2}$ Maakond (plural - maakonnad) - Estonian: maa - land, kond - county. Before the $13^{\text {th }}$ century the following counties appeared: Saaremaa (Osilia), Läänemaa (Rotalia or Maritima), Harjumaa (Harria), Rävala (Revalia), Virumaa (Vironia), Järvamaa (Jervia), Sakala (Saccala), and Ugandi (Ugaunia) (Raun, 2001, p. 11). Today's Estonia consists of 15 counties (maakonnad), 13 on the continent and 2 on the islands.
} 
related to activity of singing associations and the pan-Estonian song festival in Dorpat organized in 1869. During the Song Day that gathered around 20,000 people, not only Estonian compositions were performed (including patriotic songs), but also national ideas were presented publicly. The way the festival was organized, and especially the engagement of Estonians, were a proof that there was a strong community spirit (Lewandowski, 2001). Later, associations and other organizations emerged that were of key importance for the consolidation of the national movement. They included: Association of Estonian Writers (1872), Estonian Students' Society (1883), Estonian Alexander School, and Estonian Saving and Credit Union (1902). Significant individual liberties were introduced and political parties, trade unions and newspapers (Sakala, Valgus, Postimees) were permitted. The increasing activity of Estonians led to the appearance of more daring statements presented by political activists who manifested their unrest and put forward national demands, especially during favorable times of the 1905 Russian Revolution. Despite significant post-revolution repressions, the Estonian National Progressive Party, Estonia's first political party, was still active and its representatives were elected to the first term of the Imperial Duma and to the following terms (Lewandowski, 2002). For Estonia the period before the outbreak of WW1 was the time of intensive industrialization: the development of corporate movement (dairy production), textile industry, metal and machine manufacturing companies or paper mills (especially after 1910). Intensive urbanization and appearance of rail network acted as important stimuli of the development.

The turbulent period of WW1 turned out to be crucial for Estonia and autonomy was of key importance in the process of creating the independent state. By the decree issued on March 30, 1917 by the Provisional Government, all lands inhabited by Estonians were united into one governorate, and administrative organs and parliament (Provisional National Council) were established (Davies, 2010). This raised aspirations of Estonian politicians even more as they started demanding an independent state. After the October Revolution, on February 24, 1918 , Estonia for the first time declared independence, even though it was only for a short time. Right after the independence was proclaimed, from February till November 1918, Germany occupied Estonia and later the Red Army stepped in. After German forces had withdrawn, Estonia experienced a "great test", the Liberation War. Supported by Great Britain and Finland, Estonians managed to repulse Bolshevik aggression. Between 1918 and 1920 Estonians fought defending their independent state. The fights ended on February 2, 1920 in Tartu, when a treaty 
was signed and Soviet Russia recognized independence of Estonia. Signing the peace treaty and the end of war opened the way to international recognition of Estonia. For the first time in their history Estonians had an independent state.

During the interwar period, Estonia searched for its own national way which was difficult as it did not have its own state traditions (Sagan, 2018). For Estonia, the two decades of independence were, as in case of other states of Europe (Poland, Lithuania, Latvia), the transition from a parliamentary democracy to authoritarianism. The public order of the country was determined in the constitution approved by the Constituent Assembly on April 15, 1920. Pursuant to its provisions, Estonia was a parliamentary democratic republic in which the power belonged to the people. Executive power was vested in the government, the legislative power in the 100-member Estonian Parliament (Riigikogu); there was no president. Local governments were introduced in communes, cities and counties. The constitution guaranteed wide individual liberties (Sagan, 2009). The young state turned out to be surprisingly effective in the areas of administration and economy which significantly strengthened its stability. As early as in 1918, the national currency - the Estonian mark - was adopted. Later, in 1928, it was replaced by the Estonian kroon. The effective agricultural reform ended hundreds of years of economic and political domination of the Baltic German minority and increased the number of small farmers who established tens of thousands new farms. Despite deep economic crisis of 1924, the economic politics of Otto Strandman, the then minister of finance, helped finish the crisis. At the end of $1920^{\text {s }}$ Estonia had already successfully integrated with the European economic area (Pajur, 2012).

Political life of the interwar Estonia was characterized by rather difficult conditions of existence intensified by the multi-party system, government instability and frequent political crises. The main cause of instability was the growing influence of communists supported by the Soviet Union and the Comintern. After an unsuccessful attempt of a coup in December 1924, the aim of which was the communist seizure of power and later Sovietization and annexation of Estonia, the communist movement lost support in the country. A few years of political stability were followed by another series of failures that occurred in the late $20^{\text {s }}$ and early 30s. The economic crisis happened together with a political crisis and the growing social unrest. After a military coup orchestrated in March 1934, the period of authoritarian rule started known as the "Era of Silence", which lasted till the outbreak of WW2. 
The Soviet policy towards Estonia and its neighbours, Lithuania and Latvia, embodied strategic aims of USSR, i.e., expansion westwards and annexation and Sovietization of the three Baltic states. Soviets used different means including diplomatic pressure, political blackmail, demonstration of power (concentration of Soviet forces in bases located in Estonian territory), which led to gradual limitation of the country's independence, and finally to its annexation in August 1940 (Roman, 2010). Undoubtedly, WW2 was a tragic period for Estonia. The country lost independence and attempts to regain it during the following years claimed lives of thousands of its citizens. Between 1939 and 1945, as a result of common terror Estonia lost 280,000 citizens in total: executed, killed in action, imprisoned, deported, mobilized, forcefully evacuated and those who fled the country ${ }^{3}$. It is estimated that during that time, as a result of Soviet and German occupation, Estonia lost $25 \%$ of its population (The White Book, 2005). Additionally, over half of housing resources was lost as well as $45 \%$ of industry and $40 \%$ of the railway network (Lewandowski, 2001). It is difficult to assess other loses, in the area of culture, science, agriculture, or environment. Pursuant to the decision of Soviet authorities, Estonia lost 5\% of its territory that was incorporated into Russian FSR (around 2,500 km²), i.e., Petseri County (Petserimaa) and lands east of Narva that nowadays still remain under Russian control (Raś \& Tarnogórski, 2020).

1944-1991

\section{HALF-CENTURY OF RUSSIAN DOMINATION}

The reality of the Soviet Estonian state was analogous with the reality of the other USSR's republics. Soviet activities aimed at complete reorganisation of Estonia and its quickest possible integration with the Soviet empire. The successfully executed plan of restructuring consisted of uncompromising and directed operations starting from the administrative reform of the state, through actions within political, economic, demographic and social areas. The tactics adopted by authorities was based on terror and repressions against Estonian society and aimed at suppressing any activities that could act to the detriment of the new authority. Towards ordinary citizens, representatives of educational or cultural

\footnotetext{
${ }^{3}$ War emigrants created ethnic communities in Sweden, the USA, Canada, Great Britain, Australia and other countries. They continued lobbying for rights of Estonia for the following 50 years.
} 
institutions, artists and also towards party members of all levels and state activists, NKVD applied a number of methods - waves of brutal deportations, arresting people suspected of being members of guerrilla groups (AKA forest brothers) and their families (Lewandowski, 2002) (Table 1).

Table 1. Loss of Human Life in Estonia during Soviet Occupation (1944-1989)

\begin{tabular}{|l|c|c|c|}
\hline Category & Total & Survived & Irreversible losses \\
\hline Arrested & 30,000 & 20,000 & 10,000 \\
\hline Deported & 23,000 & 20,000 & 3,000 \\
\hline Killed during guerrilla war & 3,000 & & 3,000 \\
\hline $\begin{array}{l}\text { Arrested due to political reasons } \\
\text { in 1953-1989 }\end{array}$ & 500 & & \\
\hline
\end{tabular}

Source: based on The White Book (2005).

Social restructuring was also carried out through means that aimed at elimination of the Estonian separateness for Soviet socialist realism. Soviet repressions, censorship, destroying Estonian cultural heritage and Russification finally made artists and scientists flee the country ${ }^{4}$ and culture in ESSR had to follow strict ideological guidance.

The industry, destroyed during the war, was partly recovered and as an element of a centrally planned economy was subordinate to Moscow. Due to the planned economic unification with the Soviet Union all banks were nationalized and as a result of the monetary reform the Estonian kroon was replaced by the Soviet ruble. Command-and-quota system was introduced, the private sector was eradicated, central planning was introduced and the process of compulsory collectivism of agriculture was completed. As planned, Estonia in a short time became a part of the unionwide economic system. The process of transformation, due to ideological reasons, was described as the Socialist Reconstruction of the Estonian Economy in the Post-War Years. Decisions taken by the union

4 Estonian emigrants in Sweden, Germany, the United States or Canada were very active in the field of culture. They organized activity of cultural institutions and organizations abroad. Together with Latvians and Lithuanians they started independence movement that internationally raised the issue of occupation of the Baltic states by the Soviet Union. In 1965, at their initiative, along with thaw of 1965, the BATUN - Baltic Appeal to the United Nations - was established, an important centre for the diaspora of the Baltic nations under the Soviet occupation (Okas Ainso, 2018). 
authorities were typical examples of a classic colonisation because they were based on deliberate destroying of the national economic structure created in 1920-1940, and development of production that served the occupant's interests. To achieve this, means were invested into heavy industry (including military industry), e.g., the construction of resources concentration centre in Virumaa. It was supposed to be a facility producing electricity, gas and fuel of the local oil shale, produced for Leningrad and the Soviet Baltic Fleet (The White Book, 2005). Estonian economy developed as planned by the Soviet authorities. The heavy industry that produced for the Soviet Union was meant to be the foundation of the ESSR's economy. Industrialisation was at the expense of other branches of the economy, especially the fully collectivized agriculture (creation of collective farms, AKA kolkhoz). Leadership in Moscow, following principles of the order economy, paid no attention to local resources or labour force, traditional methods of agricultural production or local needs. For Estonia, $60^{\mathrm{s}}$ and $70^{\mathrm{s}}$ was the period of dynamic industrialisation and urbanization, the consequence of which was increase of economic migrations from the neighbouring Soviet republics. This process led to a considerable change to the ethnic structure of the republic. Still in 1945, Estonia was a homogeneous society. Among the immigrants, Russians were the most numerous (unqualified workers from cities, rural population, Soviet military men). Influx of foreigners changed the ethnic structure of the state (Lewandowski, 2002).

Table 2. Ethnic Structure of Estonia 1945-1989

\begin{tabular}{|l|c|c|c|c|c|}
\hline Year & $\begin{array}{c}\text { Population of } \\
\text { Estonia }\end{array}$ & $\begin{array}{c}\text { Number of } \\
\text { Estonians }\end{array}$ & \% of Estonians & $\begin{array}{c}\text { Number of } \\
\text { Russians }\end{array}$ & \% of Russians \\
\hline 1945 & 854,000 & 831,000 & 97.3 & & \\
\hline 1959 & $1,196,791$ & 892,653 & 74.6 & 240,227 & 20.1 \\
\hline 1970 & $1,356,079$ & 925,157 & 68.2 & 334,620 & 24.7 \\
\hline 1979 & $1,464,476$ & 947,812 & 64.7 & 408,778 & 27.9 \\
\hline 1989 & $1,565,662$ & 963,281 & 61.5 & 474,834 & 30.3 \\
\hline
\end{tabular}

Source: Eesti Statistikaamet [Statistical Office of Estonia] (1995).

Environmental degradation, especially in the north-eastern part of the country, where heavy industry was located, was another consequence of USSR's policy (next to the systematic influx of Russian immigrants). When in 1987 a plan was developed to open another phosphorite mine, organized social 
movements boycotted against Soviet ideas. Waves of protest of Estonians who together defended the environment were the spark that started great political movement that united the nation around the idea of restoring independence. The "phosphorite war" consolidated national public moods releasing the social energy of Estonians that was supressed by the regime. A new chapter in Estonian history was opened in the end of $1980^{\text {s }}$ and it was referred to as the "singing revolution". A series of nonviolent demonstrations against the Soviet rule was the background for the collapse of the Soviet empire. Mobilisation of Estonians and demonstrations in the following months became more intensive. The Estonian nonviolent revolution focused on mass night singing, patriotic speeches, song festivals (the one organized in Tallin in 1988 gathered 300,000 people, i.e., 1/4 of the whole population), participation in the "Baltic Way" (a living chain of two million people - $600 \mathrm{~km}$ long - connecting Tallin, Riga, and Vilnius) (Rytko, 2013). The dynamics and turn of the international situation at the end of 1980s, political and economic crisis, and protests in the satellite countries contributed to a split inside the empire. All those circumstances finally led to irreversible changes and in 1991, Estonia regained independence.

\section{INDEPENDENT REPUBLIC OF E-STONIA}

For the small Estonian state the half-century of Soviet domination was the period of civilizational regression. Every area of functioning of the state was affected by losses and backwardness. Intensive industrialization carried out for the Soviet Union (mainly mining) led to neglect of other sectors of the economy and to devastation of the environment. The centrally planned economy in consequence caused stagnation, drop in trade exchange and increase of unemployment. As Estonia was isolated from the Western world, it was excluded from technological revolution and the level of innovation was extremely low. An increase in prices in early $90^{\text {s }}$ (79\% in 1990) and hyperinflation (1053\% in 1992) were a proof that the state was in a dramatic situation (Laar, 2006). But once the country regained independence, mechanisms of transformation started that were meant to guide the country towards a democratic state under the rule of law based on free-market economy. The course towards normality started very rapidly. In 1992, the country had already conducted the first democratic parliamentary and presidential elections, had a new constitution, new government, president, new law and currency - the kroon. Radical and unhesitating decisions of Mart 
Laar's government initiated far-reaching political and economic reforms. For the restoring state, that created framework of effective operation. The period of transformation was a very turbulent time both in terms of political movements and society's reactions to radical decisions of the government. It was decided to go into a shock therapy that was preceded by lustration. New political elites consisted of 30-year-olds who had no connection with the communist past. And even though the age of those at power seemed a controversial issue (especially among the opposition) and thrilled the society, it did not stop them from taking unpopular, ultraliberal, but as time showed, right decisions (Laar, 2006).

The process of privatisation started with passing the law on foundations of the property reform in 1991. Within the following seven years apartments, land and companies were privatised. At the same time, despite criticism, reprivatisation was carried out (Kore, Ainsaar, \& Hendrikson, 1996). The privatisation reform was preceded by the reform of public administration the aim of which was to eliminate any abuse (Spendel, 2017). Prices and trade were deregulated, the media were privatized and actions taken attracted foreign investors. For Estonians all that was new yet painful experience in the first years of independence. As a result of economic liberalization the situation got worse for a while, but finally, after 1993, Estonian economy started to stabilize, especially from macro-economic perspective. Already in 1995 indexes showed more and more significant growth which clearly translated into a higher living standard (Laar, 2006).

Political elites were building a new face of Estonia. The aim was to re-identify the country towards a Nordic-Western republic and there was a cross-party political consensus to achieve it (modernisation processes, pro-EU and proNATO orientation ${ }^{5}$ ). Long-lasting Sovietization of the state, economic dependence on Russia, existence of Russian enclaves (civilian and military) put Estonia in an unfavourable situation right after it had regained independence, and thus breaking with Soviet heritage in all aspects of social life was a driving force for Estonian political elites. As a result, the leadership of the small Estonian republic, facing unfavourable geopolitical conditions (in the shadow of Russia), successfully took efforts to strengthen the state's stability through creating a new image of the country. Estonia decided to focus on creating digital infrastructure and investment into innovative solutions. Vicinity of Scandinavia was of key importance. Ventures undertaken with Scandinavian countries, especially Finland, were

5 Estonia became a member of NATO and the EU already in 2004. What is more, it was the first post-Soviet state to adopt Euro. 
an important determinant of the Estonian digital modernization. The decision to build a new formula of the state, based on advanced IT technology, was also taken because of poor condition of respective branches of industry, low tourist attractiveness (weather, transportation) and poor condition of infrastructure in general. The decision-makers focused on IT solutions almost in every area of life, both in the state administration as well as in everyday life. The size of the country and its demographic potential favoured that. Liina Areng argues that creativity and "being smart" guaranteed success of Estonia, which, as a small state, was better prepared to technological changes and innovative adaptation (Areng, 2014). Investment into technology reduced management costs and at the same time increased effectiveness of public services. The process of privatisation of the national telecom operator, in cooperation with Swedish and Finnish companies, started in 1992. That helped create foundations for the fibre-optic network. The first Internet connection appeared already in 1992 at universities of Tartu and Tallin. The digital reform started with the Tiger Leap program (1996) which computerised systems of education and state administration. Before 1999, all schools in Estonia were computerised and equipped with virtual platforms (Dzierżek, 2015). Gradually the model of a state based on IT was implemented. The next step was to create e-administration that would be reliable, efficient, digital, and, above all - cheap. The X-Road System ${ }^{6}$, an integrated set of public administration platforms, made it possible to lower administrative costs, accelerated decision making processes, and, above all, revolutionised functioning of the Estonian society. Private initiatives, especially electronic communication companies, developed rapidly along with processes of modernisation and digitalisation of the public service sector.

The significance attached to the development of digital public services and adopted smart solutions are widely appreciated and referred to as the Estonian smart power. The e-state is the foundation of the international image of Estonia. Good economic atmosphere, low level of bureaucracy, easy access to public services, high level of education - these are features that not only made Estonia the pioneer of innovation in e-administration, but also the cradle of many companies that achieved international success (Bolt, Play Tech, Skype, TransferWise), it also became a paradise for start-ups. The country's openness and its adaptation capac-

6 The X-Road platform offers citizens a wide spectrum of e-services: e-Voting, e-Banking, e-ID, e-Tax Board, e-Business, e-Ticket, e-Land, e-Law, e-Justice, e-Notary, e-Police, e-Governance Academy, and others. 
ity contributed to its re-orientation into one of world's most innovative places. The Republic of Estonia ranks high among global leaders (see Table 3). Due to the above, the contemporary Estonian state is an unquestioned leader of both Baltic as well as Soviet transformation.

Table 3. Position of Estonia in Selected Rankings (with Reference to the Position of Poland and Finland)

\begin{tabular}{|c|c|c|c|c|c|}
\hline Rankings & Area & $\begin{array}{l}\text { Position } \\
\text { of Estonia }\end{array}$ & $\begin{array}{l}\text { Position } \\
\text { of Finland }\end{array}$ & $\begin{array}{l}\text { Position } \\
\text { of Poland }\end{array}$ & Source \\
\hline $\begin{array}{l}\text { Global Innovation Index } \\
2020 \text { (GII) } \\
\text { Report of WIPO -World } \\
\text { Intellectual Property } \\
\text { Organisation }\end{array}$ & $\begin{array}{l}\text { innovation } \\
\text { performance }\end{array}$ & 25 & 7 & 38 & $\begin{array}{l}\text { https://www. } \\
\text { wipo.int/edocs/ } \\
\text { pubdocs/en/ } \\
\text { wipo_pub_- } \\
\text { gii_2020.pdf }\end{array}$ \\
\hline $\begin{array}{l}\text { World E-Government } \\
\text { Leaders } 2020 \\
\text { Index EGDI - E-Govern- } \\
\text { ment Development Index } \\
\text { in } 2020 \text { UNO Report }\end{array}$ & $\begin{array}{l}\text { level of } \\
\text { e-administration } \\
\text { EGDI describes three } \\
\text { elements important } \\
\text { for the development } \\
\text { of e-administration: } \\
\text { OSI - Online Service } \\
\text { Index, TII - Tele- } \\
\text { communication } \\
\text { Infrastructure Index, } \\
\text { HCI - Human Capital } \\
\text { Index }\end{array}$ & $\begin{array}{c}3 \\
{ }^{\star} 1 \\
\text { position } \\
\text { higher } \\
\text { than } \\
\text { Finland }\end{array}$ & 4 & 24 & $\begin{array}{l}\text { https://publi- } \\
\text { cadministra- } \\
\text { tion.un.org/ } \\
\text { egovkb/en-us/ } \\
\text { data-center }\end{array}$ \\
\hline $\begin{array}{l}\text { Human Development } \\
\text { Index (HDI) }\end{array}$ & $\begin{array}{l}\text { human development } \\
\text { indexes }\end{array}$ & 30 & 12 & 32 & $\begin{array}{l}\text { http://hdr. } \\
\text { undp.org/en/ } \\
\text { content/2019- } \\
\text {-human-deve- } \\
\text { lopment-index- } \\
\text {-ranking }\end{array}$ \\
\hline $\begin{array}{l}\text { World Press Freedom } \\
\text { Index } 2020\end{array}$ & freedom of media & 14 & 2 & 62 & $\begin{array}{l}\text { https://rsf.org/ } \\
\text { en/ranking }\end{array}$ \\
\hline $\begin{array}{l}\text { International Tax Com- } \\
\text { petitiveness Index } 2020\end{array}$ & tax competitiveness & $\begin{array}{c}1 \\
{ }^{*} \text { world } \\
\text { leader }\end{array}$ & 16 & 34 & $\begin{array}{l}\text { https://tax- } \\
\text {-competition. } \\
\text { org/ }\end{array}$ \\
\hline
\end{tabular}




\begin{tabular}{|l|l|c|c|c|l|}
\hline Rankings & Area & $\begin{array}{c}\text { Position } \\
\text { of Estonia }\end{array}$ & $\begin{array}{c}\text { Position } \\
\text { of Finland }\end{array}$ & $\begin{array}{c}\text { Position } \\
\text { of Poland }\end{array}$ & Source \\
\hline & & & & & $\begin{array}{l}\text { https://bran- } \\
\text { directory.com/ } \\
\text { globalsoftpo- } \\
\text { wer/download/ } \\
\text { brand-finance- } \\
\text {-global-soft- } \\
\text { Global Soft Power Index } \\
\text {-power-in- } \\
\text { dex-2020.pdf }\end{array}$ \\
\hline soft power & 47 & 21 & 35 & 1 & $*$ EU only \\
$\begin{array}{l}\text { Global Cybersecurity } \\
\text { Exposure Index 2020 }\end{array}$ & cybersecurity & $\begin{array}{l}\text { (nd only } \\
\text { cybersecurity- } \\
\text {-exposure- } \\
\text {-index/ }\end{array}$ \\
\hline
\end{tabular}

Source: author's own summary.

\section{SUMMARY}

Centuries of Estonia's history were filled with turbulence, dramatic circumstances, times of confusion and unexpected changes. Historical processes in which Estonian people took part were significant determinants of the development and shaping national identity so eagerly supressed by powers over centuries. The shaped historic identity, based on unusually strong community spirit of this nation, facing further difficulties resulting from aggressive policy of international players, was a kind of political, cultural and social capital of the nation, and later of the state. The interwar period created a possibility to start efficient mechanisms of shaping a new, spiritual identity, the main task of which was to create a cultural cohesion of the Estonian society. The Estonian regional identity for ages had been characterised by strong ethnic (Finno-Ugric) and historical influence as well as by political liking of Finland. This is the reason why the shift from its eastern "Russian Baltic" image towards the "Nordic-European" was such a great challenge. Two generations of Soviet domination was a period of strong internal opposition of the Estonian people to the social and economic structure of the Soviet Union. In Estonian history, ideas of socialism were never popular and in fact, the society never accepted those. This fact motivated and 
strengthened Estonian dislike of decisions and actions of the USSR. The Baltic question was present throughout the whole period after the annexation of the country by Moscow. Estonians themselves, both as political emigrants and as citizens of the Estonian SSR, cultivated their national identity against the odds. That was one of the reasons why the sense of sovereignty exploded in 1991 and the modern national identity was consumed to build civic society and restore the state modelled after Western democracies in the 1990s. As it was presented in the article, the digital revolution, dynamically conducted in Estonia at the end of the $20^{\text {th }}$ century and the beginning of the $21^{\text {st }}$ century, built up the present reputation of the country as an unquestioned leader of application of modern IT solutions in administration, economy and even in the foreign policy (smart power). The bold restructuring of the country and geopolitical movement towards the Nordic space turned out to be the recipe for success. Today's Estonia is a modern digital state that respects democratic and humanitarian values and this label quickly replaced perception of Estonia as a post-Soviet state.

\section{REFERENCES:}

Areng, L. (2014). Lilliputian States in Digital Affairs and Cyber Security. The Tallin Papers. A NATO CCD COE Publication on Strategic Cyber Security, 4. Retrieved from: https://ccdcoe.org/uploads/2018/10/TP_04.pdf.

Bazylow, L. (1985). Historia Rosji. Vol. 1 (pp. 131-140). Warszawa: Państwowe Wydawnictwo Naukowe.

Davies, N. (2010). Zaginione królestwa. Kraków: Społeczny Instytut Wydawniczy ZNAK.

Dzierżek, A. (2015, April 22). Cud technologiczny na pótnocy Europy. Jak Estonia stała się internetowa potęga i państwem bez granic. Retrieved from: https://forsal.pl/ artykuly/865849,cud-technologiczny-na-polnocy-europy-jak-estonia-stala-sieinternetowa-potega-i-panstwem-bez-granic.html.

Eesti Statistikaamet [Statistical Office of Estonia] (1995). Eesti rahvastik rahva-loenduste andmetel. Population of Estonia by Population Censuses. Vol. 1. Tallinn. Retrieved from: file:///Eesti\%20rahvastik\%20rahvaloenduste\%20andmetel.\%20I.\%20Population\%20of\%20Estonia\%20by\%20Population\%20Censuses\%20(1).pdf.

Forycki, M. (2007). Wpływ wojen północnych na dzieje Europy w opiniach myślicieli francuskiego oświecenia. In: B. Dybaś, \& A. Ziemlewska (eds.). Wojny północne w XVI-XVIII wieku. W czterechsetlecie bitwy pod Kircholmem (pp. 269-279). Toruń: Wydawnictwo Naukowe Uniwersytetu Mikołaja Kopernika.

Global Cybersecurity Exposure Index (CEI) (2020, June 2). By Joshua Frisby. Retrieved from: https://passwordmanagers.co/cybersecurity-exposure-index/. 
Global Innovation Index (2020). S. Dutta, B. Lanvin, \& S. Wunsch-Vincent (eds.). Who Will Finance Innovation? Ithaca, Fontainebleau, Geneva: Cornell University, INSEAD, WIPO. Retrieved from: https://www.wipo.int/edocs/pubdocs/en/ wipo_pub_gii_2020.pdf.

Global Soft Power Index 2020. The World's Most Comprehensive Research Study on Perception of Soft Power (2020). Retrieved from: https://brandirectory.com/ globalsoftpower/download/brand-finance-global-soft-power-index-2020.pdf.

International Tax Competitiveness Index (2020). Tax Foundation. Finland. Retrieved from: https://tax-competition.org/finland.

Kore, J., Ainsaar, M., \& Hendrikson, M. (1996). Prywatyzacja jako czynnik stratyfikacji społecznej w Estonii. In: W. Kosiedowski (ed.), Transformacja społeczno-gospodarcza postkomunistycznych państw bałtyckich. Doświadczenia i perspektywy (pp. 140-141). Toruń: Wydawnictwo Uniwersytetu Mikołaja Kopernika.

Laar, M. (2006). Estoński cud. Warszawa: Wydawnictwo ARWIL.

Lewandowski, J. (2001). Estonia. Warszawa: Instytut Historyczny Uniwersytetu Warszawskiego, Wydawnictwo TRIO.

Lewandowski, J. (2002). Historia Estonii. Wrocław-Warszawa-Kraków: Zakład Narodowy im. Ossolińskich.

Okas Ainso, S. (2018). The Story of BATUN - Baltic Appeal to the United Nations (1966-1991). [United States of America].

Pajur, A. (2012). Years of Parliamentarian Democracy. Retrieved from: http://www. estonica.org/en/History/1920-1939_The_Republic_of_Estonia_between_the_two_ World_Wars/Years_of_parliamentarian_democracy/.

Piirimäe, P. (2011). The Idea of "Yule Land". Baltic Provinces or a Common Nordic Space? On the formation of Estonian Mental Geographies. Baltic Worlds, 4(4), $36-39$.

Raun, T.U. (2001). Estonia and the Estonians (2 ${ }^{\text {nd }}$ ed.). Stanford, CA: Hoover Institution Press, Stanford University.

Roman, W.K. (2010). Polityka Związku Radzieckiego wobec państw nadbałtyckich (Litwy, Łotwy, Estonii) we wrześniu i październiku 1939 roku. Europa Orientalis. Studia z Dziejów Europy Wschodniej i Państw Battyckich, 2, 199-218. DOI: 10.12775/ EO.2010.011.

Rytko, K. (2013, January 7). Śpiewająca rewolucja, czyli estoński kurs na niepodległość. Liberté! Retrieved from: https://liberte.pl/spiewajaca-rewolucja-czyli-estonski-kursna-niepodleglosc/.

Sagan, S. (2009). Międzywojenne konstytucje Estonii. In: B. Mikołajczyk, \& J. Nowakowska-Małusecka (eds.). Prawo międzynarodowe, europejskie i krajowe - granice i wspólne obszary. Księga jubileuszowa dedykowana Profesor Genowefie Grabowskiej (pp. 486-495). Katowice: Wydawnictwo Uniwersytetu Śląskiego.

Sagan, S. (ed.) (2018). Ustrój państwowy Republiki Estonii. Rzeszów: Wydawnictwo Uniwersytetu Rzeszowskiego.

Spendel, M. (2017). Jak zostać tygrysem Europy. Warszawa: Polsko-Amerykańska Fundacja Edukacji i Rozwoju Ekonomicznego PAFERE: QBS Jan Kubań. 
Raś, K., \& Tarnogórski, R. (2020, February 13). Estońsko-rosyjski spór graniczny. Biuletyn Polskiego Instytutu Spraw Międzynarodowych, 23.

Tacyt, K.K. (1804). Germania. Trans. A.S Naruszewicz. Vol. 4. Warszawa: Edycya Tadeusza Mostowskiego.

The White Book (2005). Vello Salo, Okupatsioonide Repressiivpoliitika Uurimise Riiklik Komisjon, The White Book: Losses Inflicted on the Estonian Nation by Occupation Regimes 1940-1991. Estonian State Commission of Examination of the Policies of Repression - ESCEPR. Tallinn: Riigikogu kantselei.

United Nations E-Government Development Index (2020). Retrieved from: https:// publicadministration.un.org/egovkb/en-us/data-center.

United Nations Human Development Index Ranking (2019). Retrieved from: http://hdr. undp.org/en/content/2019-human-development-index-ranking.

World Press Freedom Index (2020). Reporters without Borders. Retrieved from: https:// rsf.org/en/ranking. 